\title{
TITLE VII: THE CONTINUING CHALLENGE OF ESTABLISHING FAIR EMPLOYMENT PRACTICES*
}

\author{
Julius L. Chambers $†$ \\ AND BARRY GOLDSTEIN**
}

\section{INTRODUCTION}

The continuing challenge of Title VII is, in a way, a personal theme for both of us. One of us was admitted to the bar shortly before the passage of Title VII, ${ }^{1}$ and during each week of his practice since the effective date of Title VII, July 2, 1965, he has worked on one or more Title VII actions. The other has worked on Title VII cases since 1971. Nevertheless, we do not want to dwell on the particular issues involved in the cases with which we have been associated; rather, we will review the general progress, or lack thereof, during the past two decades, and related developments in Title VII law. Moreover, we will step back and make some observations regarding these twenty years in the history of our country's attempt to deal with the effects of slavery, racial segregation, and discrimination. Finally, we will comment on the debate today regarding Title VII civil rights law and policy generally and examine the important role the Equal Employment Opportunity Commission (EEOC) needs to play in the evolution of Title VII policy.

\section{II}

\section{Historical Context}

A recent Justice Department brief attacking affirmative action ${ }^{2}$ fails to mention in any way the history of employment discrimination. ${ }^{3}$ Yet, Title VII

\footnotetext{
Copyright $\odot 1986$ by Law and Contemporary Problems

* This article was made possible by funds provided by the Charles $\mathrm{H}$. Revson Foundation. The statements made and views expressed, however, are solely the responsibility of the authors. An earlier version of this article was published under the title Title VII at Twenty: Twenty Years of Commitment to Ending Discrimination Is Not Sufficient to Eradicate the Legacy of More Than 300 Years of Racial Oppression, in 1 LABOR Law. 235 (1985). Copyright (C American Bar Association.

$\dagger$ Director, NAACP Legal Defense and Educational Fund, Inc.

* Assistant Counsel, NAACP Legal Defense and Educational Fund, Inc.

1. Civil Rights Act of 1964, tit. VII, Pub. L. No. 88-352, 78 Stat. 241, 253 (codified as amended at 42 U.S.C. $\$ 2000$ e to $2000 \mathrm{e}-17$ (1982)).

2. Brief of the United States as Intervenor-Appellee on rehearing en banc, Williams v. City of New Orleans, 729 F.2d 1554 (5th Cir. 1984).

3. Employment discrimination is " 'an unfortunate and ignominous page in this country's history." " Albemarle Paper Co. v. Moody, 422 U.S. 405, 418 (1975) (quoting United States v. N.L. Indus., Inc., 479 F.2d 354, 379 (8th Cir. 1973)).
} 
and the post-Civil War amendments ${ }^{4}$ were intended to remedy the practices and effects of racial oppression and discrimination. It is a grievous error, from both social policy and legal viewpoints, to divorce, as does the Justice Department, these constitutional and statutory enactments from the real world problems they were intended to address. The disadvantages of slavery, economically, socially, and educationally, are well known. ${ }^{5}$ The post-Civil War congresses, the congresses which fashioned the fourteenth amendment, knew full well the harsh effects of slavery and designed race-conscious remedies to end those effects. These race-specific measures were adopted over the objections of critics who opposed such special assistance for a single racial group. The most far-reaching of these programs, the 1866 Freedmen's Bureau Act, ${ }^{6}$ was enacted almost simultaneously with Congress' approval of the fourteenth amendment. The Freedmen's Bureau was authorized to use the lands and buildings of the confederate states, or the proceeds from the sale or rental of the properties for "the education of the freed people," 7 but not for whites. The range and diversity of the race-specific measures, such as the one creating the Freedmen's Bureau, is striking. ${ }^{8}$ It is inconceivable that the Thirty-Ninth Congress, which was well aware of the race-conscious remedies and limitations contained in the Freedmen's Bureau bills it passed in February and July of 1866 , intended by its approval of the fourteenth amendment on June 12,1866, to invalidate or forbid such remedies and limitations. The present-day opponents of race-conscious remedies ignore the historic context of the fourteenth amendment when they argue that the fourteenth amendment must be applied in a "color-blind" manner.

The Reconstruction period was short-lived. In the words of Justice Thurgood Marshall, "[s]lavery was replaced by a system of "laws which imposed upon the colored race onerous disabilities and burdens, and curtailed their rights in the pursuit of life, liberty, and property to such an extent that their freedom was of little value." "9 Similarly, a historian of this period noted that " $[\mathrm{b}] \mathrm{y}$ narrow and ingenious interpretation [the Supreme Court's] decisions over a period of years had whittled away a great part of the authority presumably given the government for protection of civil rights."10

4. U.S. Const. amends. XIII-XV; see also The Civil Rights Act of 1870 \& 1871,42 U.S.C. $\S \S 1981,1983$ (1982).

5. See generally Regents of the Univ. of Cal. v. Bakke, 438 U.S. 265, 387-90 (1978) (opinion of Marshall, J.).

6. Act of July 16, 1866, ch. 200, 14 Stat. 173. The Bureau was officially known as the Bureau of Refugees, Freedmen and Abandoned Lands. See Act of March 3, 1865, ch. 90, 13 Stat. 507.

7. Act of July 16, 1866, ch. $200, \S 12,14$ Stat. 173,176 .

8. The history of this race-specific, post-Civil War legislation is set forth in detail in the Brief of NAACP Legal Defense and Educational Fund, Inc. as Amicus Curiae, at 10-53, Regents of the Univ. of Cal. v. Bakke, 438 U.S. 265 (1978), reprinted in 100 LANDMARK BRIEFS AND aRGuMENTS OF THE Supreme Court of the United States: Constitutional law 1977 Term Supp. 215, 243-86 (P. Kurland \& G. Casper eds. 1978).

9. Regents of the Univ. of Cal. v. Bakke, 438 U.S. 265, 390 (quoting The Slaughter-House Cases, 83 U.S. (16 Wall.) 36, 70 (1873)).

10. C. Woodward, The Strange Career of Jim Crow 139 (3d ed. 1974), quoted in Regents of the Univ. of Cal. v. Bakke, 438 U.S. 265, 391 (1978); see also W.E.B. DuBors, BLACK ReConstruction 690-91 (1935). 
As shall be described later, some courts are once again-and this time with the aid of the federal government- "whittling away" the important civil rights acts. ${ }^{11}$

The various forms of employment discrimination established after the Civil War created the patterns which existed when Title VII became effective nearly 100 years later. At the end of the Civil War blacks constituted approximately eighty percent of all skilled tradesmen in the South. ${ }^{12}$ The high proportion of black artisans flowed from the simple economic fact that a trained and skilled slave was far more valuable property than an unskilled slave. ${ }^{13}$ After the Civil War, the economic tables turned. Skilled, free blacks threatened the economic well-being of whites. The post-Civil War period saw the development of extensive efforts to limit or eliminate opportunities for black workers to use their skills or to acquire new ones. The enactment of Black Codes regulated the conditions of freedmen's labor, subjected them to the control of their former masters or other white men, and excluded them from apprentice and other training programs. ${ }^{14}$ Vocational schools to which blacks were assigned "seldom fitted them for the ... demands of the so-called 'Southern Industrial Revolution." '15 Even as late as 1961, blacks were trained only for those jobs to which they were relegated in a segregated job market. ${ }^{16}$

As unions increased their control and influence around the turn of the century, they established virtually insurmountable barriers to the employment and training of blacks. Many of the American Federation of Labor craft unions excluded blacks by express constitutional provision or by "ritual" requirements. ${ }^{17}$ Also, in their original call for membership, the International Association of Machinists solicited "white, free born male citizen[s] of some civilized country," and by their ritual restricted, until 1948, membership to "white" persons. ${ }^{18}$ Other unions denied admission to blacks or restricted their access to jobs by a series of unwritten practices, such as control of apprenticeship training and influence with licensing boards. ${ }^{19}$ It should have been no surprise, therefore, when the Supreme Court declared that "[j]udicial

11. See infra section IV.

12. 2 G. Myrdal, An American Dilemma 1101 (1972); see also S. Spero \& A. Harris, The Black WORKER 16 (1966).

6.

13. G. Myrdal, supra note 12, at 887, 1100-01; see also S. SPERo \& A. Harris, supra note 12, at 5-

14. See G. Myrdal, supra note 12, at 1101-02; S. Spero \& A. Harris, supra note 12, at 17-18.

15. C. Hall, Black Vocational, Technical and Industrial Arts Education 19 (1973); see also R. Weaver, Negro labor: A National Problem (1969).

16. F. Marshall, The Negro and Organized Labor 135 (1965); U.S. Comm. on Civil Rights, EMPLOYMENT 97 (1961).

17. See Karson \& Radosh, The American Federation of Labor and the Negro Worker, 1894-1949, in THE Negro and the American Labor Movement 155, 157-58 (J. Jacobsen ed. 1968).

18. Response of Machinists to Requests to Admit or State Facts, Terrell v. United States Pipe \& Foundry Co., 22 Fair Empl. Prac. Cas. (BNA) 1695 (N.D. Ala. 1979); see also Terrell v. United States Pipe \& Foundry Co., 644 F.2d 1112, 1119 (5th Cir. 1981), vacated and remanded, 456 U.S. 955 (1982).

19. H. Northrup, Organized Labor and the Negro 22-27 (1944); Marshall, The Negro in Southern Unions, in The Negro AND THE AMERICAN LABOR Movement, supra note 17, at $128,145$. 
findings of exclusion from crafts on racial grounds are so numerous as to make such exclusion a proper subject for judicial notice." 20

By adhering to traditional patterns of "black" and "white" jobs, employers maintained and heightened the job disadvantages of blacks. One author summed up the situation as follows: "The occupational patterns which evolved were in accord with this basic principle: clean, light, well-paid jobs for whites and heavy, dirty, lower paid jobs for Negroes."21

When Title VII was passed in 1964, these entrenched patterns of racial discrimination were essentially intact. The modest efforts of the federal government, which commenced during World War II to mitigate employment discrimination through voluntary action, were largely unsuccessful.

III

\section{ENACTMENT OF TitLe VII}

The Civil Rights Act of 1964 was the first comprehensive federal legislation ever to address the problems of discrimination against blacks in modern American society. ${ }^{22}$ The Act was passed during a period of enormous domestic turmoil. On June 11, 1963, eight days before sending to Congress the bill which became the Civil Rights Act of 1964, President Kennedy stated on national television that "[i]t is better to settle these matters in the courts than on the streets, and new laws are needed at every level." 23 The divisions of that time were reflected in the congressional battle. The bill passed the House of Representatives on February 10, 1964. A vigorous filibuster took place in the Senate. After $\mathbf{5 3 4}$ hours, one minute and thirty-seven seconds, the Senate voted cloture. The filibuster produced over 500 amendments, but the legislative history was less than clear on the intended operation of the statute. ${ }^{24}$ One point, however, is beyond dispute: Title VII, and the entire Civil Rights Act of 1964, were passed to avert a national crisis, to end the odious legacy of slavery and racial oppression, and to resolve racial conflicts "in the courts [rather] than on the streets." The Act was a remedial act-an attempt to change the conduct of Americans—on a grand scale. ${ }^{25}$

IV

\section{IMPLEMENTATION OF TITLE VII}

What has this grand remedial statute wrought? How has it worked? Is Title VII effective today and will it be effective in the future?

20. United Steelworkers v. Weber, 443 U.S. 193, 198 n.1 (1979).

21. R. Weaver, supra note 15, at 6; see also G. Myrdal, supra note 12, at 1080-82.

22. M. Sovern, Legal Restraints on Racial Discrimination in Employment 8 (1966).

23. N.Y. Times, June 12, 1963, at 20, col. 6 .

24. See Belton, A Comparative Review of Public and Private Enforcement of Title VII of the Civil Rights Act of 1964, 31 VAND. L. Rev. 905,917 (1978).

25. McDonnell Douglas Corp. v. Green, 411 U.S. 792, 800 (1973) ("The language of Title VII makes plain the purpose of Congress to assure equality of employment opportunities and to eliminate those discriminatory practices and devices which have fostered racially stratified job environments to the disadvantage of minority citizens."). 
Unlike the Reconstruction Acts, ${ }^{26}$ the early Executive Order programs, ${ }^{27}$ the "jawboning" efforts tried under the Plans for Progress, ${ }^{28}$ and state fair employment laws, ${ }^{29}$ Title VII has had a significant impact upon the barriers to equal employment opportunity. It was not inevitable that Title VII would have such an impact. Moreover, the impact of Title VII appears to be lessening and the outlook for continued progress towards assuring equal opportunity is becoming less bright.

Four primary requirements are necessary for the effective implementation of Title VII: (1) a system of procedural law which will readily permit the presentation of serious claims of employment discrimination; (2) a definition of discrimination which will include the practices which actually bar job progress; (3) an approach to remedies which will provide a spur for voluntary compliance and also provide effective means for change; and (4) the availability of adequate resources both in the private bar and in the government to implement the law. ${ }^{30}$ This section examines these four requirements and discusses recent developments which threaten the effectiveness of Title VII.

In general, two basic attitudes threaten the effectiveness of Title VII. First, some courts are moving away from interpreting Title VII as a broad remedial statute designed to deal effectively with historic patterns of discrimination and are now substituting narrow constructions of the Act. Second, the federal government is failing to take, or worse, is opposing positions which would effectively implement Title VII.

\section{A. Procedural Law}

The early years of Title VII were filled with litigation regarding the procedural implementation of the Act. Few cases were tried in the 1960's due in large part to the creative ability of the defendants' bar to devise clever procedural arguments. If the defendants' arguments-such as limiting class actions only to those persons who filed charges, requiring as a precondition to litigation that charges be investigated and conciliated within the exact time

26. 42 U.S.C. $\S \S 1981,1983$ (1982). Section 1981 was originally enacted as part of $\S 1$ of the Civil Rights Act of 1866. Act of Apr. 19, 1866, ch. 31, 1,14 Stat. 27. After the ratification of the fourteenth amendment in 1868 , the statute was reenacted in 1870 . Act of May $31,1870, \mathrm{ch} .114$, $\S \S 16,18,16$ Stat. 144. Section 1983 was enacted as part of $\S 1$ of the Civil Rights Act of 1871 , also known as the Ku Klux Klan Act. Act of Apr. 20, 1871, ch. 22, §1, 17 Stat. 13.

27. "From 1946 until 1964 , the principal federal effort to eliminate employment discrimination was in the area of government contracts. Presidents Truman and Eisenhower both established Commitees on Government Contract Compliance. Neither of these committees, however, had direct enforcement power, and studies of these programs conclude that their impact on the elimination of job discrimination was minimal." Belton, A Comparative Review of Public and Private Enforcement of Title VII of the Civil Rights Act of 1964, 31 VAND. L. Rev. 905, 910 (1978); see also M. Sovern, LeGal Restraints on Racial Discrimination in Employment 9-17 (1966).

28. See H. Hill, Black Labor and the American Legal System 380 (1985).

29. For a compilation of state fair employment laws, see 8A Fair Empl. Prac. Manual, Lab. Rel. Rep. (BNA).

30. In substantial part, this division of the development of Title VII is based upon the analysis of Professor Robert Belton. See Belton, Title VII of the Civil Rights Act of 1964: A Decade of Private Enforcement and Judicial Developments, 20 ST. LouIs U.L.J. 225 (1976); Belton, supra note 24. 
requirements of the Act, and limiting court action to the statement of the discriminatory act described on the EEOC charge-had prevailed, Title VII would have been stillborn.

Courts, however, took the view that procedural "technicalities are particularly inappropriate in a statutory scheme in which laymen, unassisted by trained lawyers, initiate the process." 31 The courts were "[m]indful of the remedial and humanitarian underpinnings of Title VII and of the crucial role played by the private litigant in the statutory scheme" 32 in permitting a specifically drawn Title VII charge to serve as a basis for a lawsuit attacking broad patterns of discriminatory practices. ${ }^{33}$ Moreover, courts recognized that "[r]acial discrimination is by definition a class discrimination," 34 and interpreted the newly modified class action rule and Title VII to permit employment discrimination class actions in a broad array of circumstances. ${ }^{35}$

In short, the courts treated Title VII as a broad remedial statute designed to change fundamentally the patterns of employment discrimination which had become ossified in the labor market. ${ }^{36}$ In the 1980's, however, courts began to announce narrow hyper-technical interpretations of Title VII. ${ }^{37}$

31. Love v. Pullman Co., 404 U.S. 522, 527 (1972).

32. Sanchez v. Standard Brands, Inc., 431 F.2d 455, 460 (5th Cir. 1970) (footnote omitted).

33. E.g., id.

34. Hall v. Werthan Bag Corp., 251 F. Supp. 184, 186 (M.D. Tenn. 1966).

35. See, e.g., Albemarle Paper Co. v. Moody, 422 U.S. 405, 414 n.8 (1975) (unnamed class members need not exhaust administrative remedies); Oatis v. Crown Zellerbach Corp., 398 F.2d 496 (5th Cir. 1968) (same).

36. Courts, and especially the appellate courts, interpreted Title VII, as did Judge Tuttle, as a "clear mandate from Congress" to end racial discrimination in employment, "one of the most deplorable forms of discrimination known to our society," and decided that "[i]t is, therefore, the duty of the courts to make sure that the Act works ...." Culpepper v. Reynolds Metals Co., 421 F.2d 888, 891 (5th Cir. 1970). This view was criticized at the time. Judge Coleman observed that "it is never the duty or the concern of the courts "to make sure the Act works." Id. at 895 (concurring opinion). Title VII's great remedial purpose would be thwarted, however, by interpreting the Act outside the context of its remedial purpose and outside the history of discrimination described in the text. The liberal procedural interpretation of the courts permitted the Act to work.

37. One example of a narrow interpretation is in General Tel. Co. v. Falcon, 457 U.S. 147 (1982). There, the Supreme Court discussed the application of the class action rule to Title VII cases in an unanimous opinion. As is often the case with unanimous opinions both the plaintiffs' and the defendants' bar perceived some support for their positions. The Court ruled that a Title VII action must meet the requirements of Federal Rule of Civil Procedure 23 in order to be treated as a "class action" but also "not[ed its] awareness "that suits alleging racial or ethnic discrimination are often by their very nature class suits." 'Id. at 157 (quoting East Texas Motor Freight Sys. v. Rodriguez, 431 U.S. 395, 405 (1977)).

It was not so much the decision promulgated by the Court nor even the arguments advanced by the Company which foreshadowed the changing tide of application of the class action rule. Rather, it was the brief submitted by the Department of Justice. The Department of Justice filed a brief amicus curiae opposing the position of the Hispanic plaintiff. The Equal Employment Opportunity Commission (EEOC), supposedly the lead agency in setting federal government employment policy, opposed and refused to sign the brief filed by the Justice Department. This brief was the first of what has become an all too common phenomenon of the Reagan Justice Department-the Department filing a brief opposing positions taken by the EEOC which, if adopted by the courts, will result in limiting the effectiveness of the Act. The critical point was not really the side taken by the Justice Department, but rather the approach of the brief. There was no recognition in the Justice Department brief of the importance of the class action device to the effective implementation of Title VII or of the class nature of discrimination. The brief.should be compared with those filed by the prior republican Administration which stated that "[m]ost Title VII actions are by their very nature 


\section{B. Definition of Unlawful Discrimination}

\section{It is difficult to conceive of a broader definition of discrimination than the} one in section 703(a)(2) of Title VII:

class actions, since they involve claims of discrimination on the basis of class characteristics," Memorandum for the United States and Equal Employment Opportunity Commission as Amici Curiae, East Texas Motor Freight Sys. v. Rodriguez, 434 U.S. 810 (1977), and that "any restriction on [class] actions would greatly undermine the effectiveness of Title VII." Brief for the United States and the Equal Employment Opportunity Commission as Amici Curiae, Albemarle Paper Co. v. Moody, 422 U.S. 405 (1975); see Brief for the United States and the Equal Employment Opportunity Commission as Amici Curiae, Franks v. Bowman Transport. Co., 424 U.S. 747 (1976).

The recent Fifth Circuit decision in Vuyanich v. Republic Nat. Bank, 723 F.2d 1195 (5th Cir. 1984), illustrates the more narrow reading which some courts are now applying to Title VII actions. In an exhaustively reasoned opinion, the district court judge, Judge Higgenbotham, had found that the Republic National Bank of Dallas had discriminated against blacks and women in many aspects of its employment practices and that the named representatives were appropriate representatives for those affected by the discrimination. See Vuyanich v. Republic Nat. Bank, 505 F. Supp. 224 (N.D. Tex. 1980) (mem.), reconsidered, 521 F. Supp. 656 (1981), vacated, 723 F.2d 1195 (5th Cir. 1984). The court of appeals severely narrowed the scope of the lawsuit and the class entitled to relief by limiting the class and restricting the scope of the EEOC administrative charge.

The plaintiffs argued that since they were discriminatorily affected by subjective discrimination, which applied generally to the practices of the bank, they could represent others similarly affected. In General Telephone Co. v. Falcon, the Supreme Court had stated that "[s]ignificant proof that an employer operated under a general policy of discrimination conceivably could justify a class of both applicants and employees if the discrimination manifested itself in hiring and promotion practices in the same general fashion, such as through entirely subjective decisionmaking processes." 457 U.S. at 147, n.15 (1982).

If the district court's decision in Vuyanich does not establish "[s]ignificant proof," it is hard to imagine an opinion that would meet this burden. Nevertheless, the Court of Appeals rejected this argument because " $[t]$ he district court's finding that the Bank relied on two objective inputseducation and experience-in its necessarily subjective hiring process . . precludes reliance on this "general policy of discrimination 'exception.'" Vuyanich, 723 F.2d at 1199-1200 (emphasis added) (citation omitted). It is difficult to explain what this analysis means, except that many individuals who have been discriminated against by the bank will not be entitled to relief and that a substantial portion of the plaintiffs' attorneys' work will be for nought and will go unrewarded.

The court's work was not finished when it limited the scope of the class. Plaintiffs had sought to intervene three individuals who could represent the broader class. However, the court barred this intervention by applying a restrictive reading to the EEOC charges which were filed. The intervenors sought to assert claims relating to promotion, transfer, compensation, and job assignment, but since they had not filed an EEOC charge, they were dependent upon the scope of the EEOC charges filed by the plaintiffs. The determination of the scope of EEOC charges, as other procedural issues, has been liberally interpreted by the courts:

[A] judicial complaint filed pursuant to Title VII "may encompass any kind of discrimination like or related to allegations contained in the charge and growing out of such allegations during the pendency of the case before the Commission ...." In other words, the "scope" of the judicial complaint is limited to the "scope" of the EEOC investigation which can reasonably be expected to grow out of the charge of discrimination.

Sanchez v. Standard Brands, Inc., 431 F.2d 455, 466 (5th Cir. 1970) (quoting King v. Georgia Power Co., 295 F. Supp. 943, 947 (N.D. Ga. 1968)). In effect, the Vuyanich court ignored this wellestablished law and ruled that "[s]ince Vuyanich and Johnson had standing to assert only sex discrimination in hiring or race discrimination in termination, Oatis v. Crown Zellerbach Corp., 398 F.2d 496 (5th Cir. 1968), is determinative of the impropriety of allowing intervention." 723 F.2d at 1201. It is peculiar that the court relies on Oatis since the court in Oatis stated that "[r]acial discrimination is by definition class discrimination, and to require a multiplicity of separate, identical charges before the EEOC, filed against the same employer, as a prerequisite to relief through resort to the Court, would tend to frustrate our system of justice and order." 398 F.2d at 499 . Again, it is unclear what the Court meant or why the concept of standing should limit the scope of an EEOC. charge.

To borrow a phrase from another area of law, opinions such as Vuyanich "chill" the enforcement of Title VII. In the words of one of the plaintiffs' attorneys in Vuyanich, the opinion 'makes it 
(a) it shall be an unlawful employment practice for an employer . .

(2) to limit, segregate, or classify his employees or applicants for employment in any way which would deprive or tend to deprive any individual of employment opportunities or otherwise adversely affect his status as an employee, because of such individual's race, color, religion, sex, or national origin. ${ }^{38}$

In the most important judicial interpretation of Title VII, Griggs v. Duke Power Company, ${ }^{39}$ the Supreme Court stated that:

The objective of Congress in the enactment of Title VII is plain from the language of the statute. It was to achieve equality of employment opportunities and remove barriers that have operated in the past to favor an identifiable group of white over other employees. Under the Act, practices, procedures, or tests neutral on their face, and even neutral in terms of intent, cannot be maintained if they operate to "freeze" the status quo of prior discriminatory employment practices.

...

. . . Congress directed the thrust of the Act to the consequences of employment practices, not simply the motivation. ${ }^{40}$

The Griggs interpretation of Title VII-the application of an effect standard-has assisted in removing unnecessary, non-job-related barriers to equal employment opportunity. Without Griggs, Title VII would have had little impact upon the historic problems of discrimination which it was intended to correct.

While Griggs has been repeatedly reaffirmed by the Court, the application of the Griggs principles has been limited. The Supreme Court has ruled that the Griggs effect standard does not apply to constitutional claims ${ }^{41}$ or to claims brought pursuant to the post-Civil War civil rights acts. ${ }^{42}$ The Court has also held that Title VI of the Civil Rights Act of $1964^{43}$ does not establish an effect standard, although administrative agencies may issue regulations pursuant to Title VI that require an effect standard. ${ }^{44}$ In keeping with the reversal of positions at the Department of Justice, the Reagan Administration refused to file a brief before the Court supporting the longstanding Title VI regulations of administrative agencies that provide for an effect standard, despite the urging of the EEOC.

impossible" for private enforcement. Telephone interview with Linda Coffey, April 17, 1984. During the ten years of the litigation, the plaintiffs put over $\$ 100,000$ in out-of-pocket costs and thousands of attorneys' hours into the prosecution of Vuyanich. Id. By a technical and inexplicable opinion, the court barred relief to many who were affected by discriminatory practices. The court also sent a message to those who seek to bring actions to implement Title VII's purpose to "eliminate those discriminatory practices and devices which have fostered racially stratified job environments," McDonnell Douglas Corp. v. Green, 411 U.S. 792, 800 (1973), that they face difficult and cumbersome procedural obstacles which may result in not only the failure of the litigation but also substantial personal loss in unreimbursed expenses and uncompensated time.

38. 42 U.S.C. $\$ 2000 \mathrm{e}-2(\mathrm{a})(2)$ (1982) (emphasis added).

39. 401 U.S. 424 (1971).

40. Id. at 429-30, 432 (emphasis in original).

41. Washington v. Davis, 426 U.S. 229, 238-39 (1976).

42. 42 U.S.C. \& 1981 (1982); General Bldg. Contractors Ass'n v. Pennsylvania, 458 U.S. 375 (1982).

43. 42 U.S.C. $\$ \S 2000 d$ to $2000 d-6$ (1982).

44. Guardians Ass'n v. Civil Serv. Comm'n, 463 U.S. 582 (1983) (In the opinions by Powell, O'Connor, and Stevens, IJ., seven justices agreed that Title VI requires proof of discriminatory intent.). 
The application of the more stringent intent standard to the Constitution, the post-Civil War civil rights act, and Title VI of the Civil Rights Act of 1964 will have a limited effect on challenges to employment practices because Title VII is usually available as an alternative. Such is not the case, though, with respect to the Supreme Court's interpretation of section 703(h) of Title VII, the "bona fide" seniority provision. 45

The issue concerning seniority systems arises from a stark fact: much of the job structure in American industry, especially in the south, was segregated when Title VII was enacted. ${ }^{46}$ It did not take a great deal of knowledge of job patterns to know which jobs were "black" jobs and which jobs were "white" jobs. For example, blacks worked in the blast furnace departments in the steel industry but not in the machine shops, as switchmen in the railroad industry but not as conductors, in the woodyard in the paper industry but not in the paper lines. The removal of the overt racial barriers to job transfer from "black" jobs or departments to "white" jobs or departments in the early 1960's accomplished little. If a black worker accepted the opportunity to transfer, the worker would, under most seniority systems, have to forfeit his or her accumulated seniority. It was not feasible for black workers "to commit 'seniority suicide' " 47 and to forfeit all job security in order to move to jobs from which they had been previously excluded. Even if a black worker desired to transfer to a "white" job, he or she would be unable to carryover his or her seniority in order to bid successfully against white workers who were already working in the department.

The legality of a seniority system which perpetuated the inferior position of black workers was one of the first issues concerning the definition of unlawful discrimination addressed by the courts. In 1968, Judge Butzner ruled "that Congress did not intend to freeze an entire generation of Negro employees into discriminatory patterns that existed before [Title VII]." 48 Without a single dissent, eight courts of appeals, in over 30 cases, agreed with Judge Butzner.49 "The Quarles view ... enjoyed wholesale adoption in the Courts of Appeals." 50 In Local 189, United Papermakers and Paperworkers v. United States, ${ }^{51}$ Judge Wisdom succinctly stated the reason: "Every time a Negro worker hired under the old segregated system bids against a white worker in his job slot, the old racial classification reasserts itself, and the Negro suffers anew for his employer's previous bias." 52

45. 42 U.S.C. $\$ 2000(\mathrm{e})-2(\mathrm{~h})$ (1982) ("Notwithstanding any other provision of this subchapter, it shall not be an unlawful employment practice for an employer to apply different . . terms, conditions, or privileges of employment pursuant to a bona fide seniority . . system .....”).

46. See supra section II.

47. James v. Stockham Valves \& Fittings, Inc., 559 F.2d 310, 348 (5th Cir. 1977), cert. denied, 434 U.S. 1034 (1978).

48. Quarles v. Philip Morris, Inc., 279 F. Supp. 505, 516 (E.D. Va. 1968).

49. International Bhd. of Teamsters v. United States, 431 U.S. 324, 378-79 (1977) (Marshall, J., dissenting).

50. Id. at $346 \mathrm{n} .28$.

51. 416 F.2d 980 (5th Cir. 1969), cert. denied, 397 U.S. 919 (1970).

52. Id. at 988 . 
The Supreme Court disagreed. In International Brotherhood of Teamsters $v$. United States, ${ }^{53}$ the Court held "that an otherwise neutral, legitimate seniority system does not become unlawful under Title VII simply because it may perpetuate pre-Act discrimination." 54 Since the Teamsters case, the Court has defined "seniority system" broadly 55 and determined that the protection of section 703(h) applies to seniority systems created after the effective date of Title VII. ${ }^{56}$

There is one fortunate aspect of the Teamsters decision-it did not come until 1977. During the decade when the Quarles ruling enjoyed "wholesale adoption" many-perhaps most-discriminatory seniority systems were changed by court order or voluntarily by companies and unions fearful of a lawsuit. One of the great achievements of Title VII is that the segregated job patterns were largely undone by the mid-1970's in the paper, steel, railroad, aluminum, foundry, and other industries. In good part, this achievement is owed to the interpretation by Judges Butzner, Wisdom and others of Title VII as a remedial statute designed to remove "barriers" to equal employment opportunity. In part, this achievement is owed to the good fortune that the Supreme Court did not decide Teamsters earlier than it did. ${ }^{57}$

\section{Provision of Adequate Remedy}

The Supreme Court has recognized the importance of an effective remedy in very practical terms. In Albemarle Paper Company $v$. Moody, ${ }^{58}$ the Court stated that back pay awards serve as the "spur or catalyst" for employers to review their employment practices and to rid them of any discrimination. ${ }^{59}$ The Court stressed that any decision regarding back pay must follow the "central [remedial] statutory purposes of eradicating discrimination throughout the economy and making persons whole for injuries suffered."60 The Court has also ruled that the proof of a pattern or practice of discrimination "supports an inference that any particular employment decision, during the period in which the discriminatory policy was in force, was made in pursuit of that

53. 431 U.S. 324 (1977).

54. Id. at 353-54.

55. See California Brewers Ass'n v. Bryant, 444 U.S. 598, 605-06 (1980) (seniority systems dispense benefits "on the basis of some measure of time served in employment").

56. American Tobacco Co. v. Patterson, 456 U.S. 63 (1982).

57. It is important to note in reviewing the accomplishments and failures of Title VII that the price for the support of the American labor movement for Title VII was $\$ 703(\mathrm{~h})$. In other words, the AFL-CIO exacted as its payment for support of Title VII the protection of the privileged position of white workers based upon intentionally discriminatory practices of job segregation.

Another aspect of the seniority issue is worthy of note. Members of the Reagan Administration continually assert their commitment to provide a remedy for all the victims of intentional discrimination. Yet no member of the Administration has ever suggested that $\$ 703(\mathrm{~h})$ should be amended in order to permit the courts to remedy the consequences of intentional discrimination in initial job assignments which are perpetuated by seniority systems.

58. 422 U.S. 405 (1975).

59. Id. at 417-18 (quoting United States v. N.L. Indus., Inc., 479 F.2d 354, 379 (8th Cir. 1973)).

60. Id. at 421 . See generally Special Project, Back Pay in Employment Discrimination Cases, 35 VAND. L. REv. 893 (1982). 
policy."61 Finally, the Court approved affirmative race-conscious relief in United Steelworkers $v$. Weber, ${ }^{62}$ declaring that: "It would be ironic indeed if a law triggered by a Nation's concern over centuries of racial injustice . . . constituted the first legislative prohibition of all voluntary, private raceconscious efforts to abolish traditional patterns of racial segregation and hierarchy." 63

The appellate court decisions in the early 1970's which held that classwide back pay was an appropriate remedy ${ }^{64}$ and the affirmation of that principle by the Supreme Court did in fact "spur" major re-evaluation of employment practices; these decisions resulted not only in voluntary compliance but also in the settlement of many pending Title VII actions. Furthermore, the appellate courts' unanimous approval of race-conscious affirmative action, ${ }^{65}$ which the Supreme Court supported in Regents of the University of California $v$. Bakke ${ }^{66}$ and United Steelworkers $v$. Weber, ${ }^{67}$ provided an effective means of breaking down the most entrenched segregated job patterns and opening up job and training opportunities which had been largely closed to blacks. ${ }^{68}$

The Supreme Court's decision in Memphis Firefighters, Local Union No. 1784 $v$. Stotts 69 did not change the judicial emphasis on effective remedies. Stotts reaffirmed the Supreme Court's long established position that contractural seniority rights should not be abrogated over the objection of the parties to the agreement absent a showing that the seniority system was the product of intentional discrimination. The Court added that a district court is without authority to confer preferences to certain individuals, who were not themselves the victims of unlawful discrimination, over the seniority rights of other individuals.

Despite the rather specific holding in Stotts, the current policymakers in the Reagan administration Justice Department are arguing with renewed vigor the position they have maintained since 1981 that under no circumstances may a court confer benefits on individuals who are not the proven victims of unlawful discrimination. Moreover, they maintain, a public employer is prohibited by the fourteenth amendment from engaging in voluntary affirmative action. ${ }^{70}$ Clearly, Stotts does not have the reach the Department of

61. International Bhd. of Teamsters v. United States, 431 U.S. 324, 362 (1977).

62. 443 U.S. 193 (1979).

63. Id. at 204.

64. See, e.g., Johnson v. Georgia Highway Express, Inc., 417 F.2d 1122, 1127 (5th Cir. 1969); Bowe v. Colgate-Palmolive Co., 416 F.2d 711 , 719 (7th Cir. 1969).

65. See U.S. Commission on Civil Rights, Affirmative Action in the 1980s: Dismantling the Process of Discrimination 24-25 (1981).

66. 438 U.S. 265 (1978).

67. 443 U.S. 193 (1979).

68. See infra section $\mathrm{V}$.

69. 467 U.S. 561 (1984).

70. These views were reiterated recently in a Justice Department appellate brief filed in the eleventh circuit. Brief for the United States as Appellant, Paradise v. Prescott, 767 F.2d 1514 (11th Cir. 1985). Paradise is the most recent chapter in the thirteen-year effort to desegregate the Alabama Highway Patrol. See NAACP v. Allen, 493 F.2d 614 (5th Cir. 1974) (earlier opinion in that case). 
Justice seeks to attach to it. The opinion itself makes it clear that it does not extend to decisions of public employers to adopt voluntary affirmative action plans which utilize numerical goals and ratios. ${ }^{71}$ Prior to Stotts, the courts of appeals had frequently affirmed the authority of district courts to order the use of remedial goals and timetables. ${ }^{72}$ The Stotts Court made no reference to any of these cases and it is inconceivable that the Court would overrule them without mentioning them.

In one decided case, the position of the Department of Justice was squarely presented and addressed. In Williams $v$. City of New Orleans, ${ }^{73}$ decided just prior to Stotts, the Fifth Circuit, sitting en banc, concluded that district courts have the authority under Title VII to order affirmative action plans which utilize goals and timetables. There was a fight within the Reagan administration over whether the EEOC would be able to file a brief expressing a view which was contrary to that being advanced by the Justice Department. Although the EEOC ultimately bowed to White House pressure and refrained from filing its brief, its attempt is commendable. It was the only federal agency expressing a willingness to support the consistent prior policy of the federal government in favor of vigorous enforcement of Title VII.

\section{Resources for Enforcement}

The internal fight between the Department of Justice and the EEOC over the scope of relief leads to the final critical element of a scheme for effective enforcement of Title VII: the availability of adequate resources to implement the law. Title VII has generated an enormous amount of activity, and lawsuits filed pursuant to Title VII have risen at a rapid rate. In 1970, when the Administrative Office of the United States Courts began to keep statistics on cases by classification, 344 Title VII cases were filed..$^{74}$ In 1983, in the Northern District of Illinois alone, there were 524 cases filed. ${ }^{75}$ The number of cases rose dramatically from 1970 until 1976 , with 5,321 cases being filed in that year. ${ }^{76}$ The number remained fairly constant through 1980 , when

71. 467 U.S. at 583.

72. E.g., Chisholm v. United States Postal Serv., 665 F.2d 482, 498-99 (4th Cir. 1981); United States v. City of Chicago, 663 F.2d 1354, 1355 (7th Cir. 1981); Firefighters Inst. for Racial Equality v. City of St. Louis, 616 F.2d 350, 364 (8th Cir. 1980); United States v. City of Alexandria, 614 F.2d 1358, 1362-63 (5th Cir. 1980); EEOC v. American Tel. \& Tel. Co., 556 F.2d 167, 174 (3d Cir. 1977), cert. denied sub nom. Communications Workers v. EEOC, 438 U.S. 915 (1978); Boston Chapter, NAACP v. Beecher, 504 F.2d 1017, 1026-28 (1st Cir. 1974); Rios v. Enterprise Ass'n Steamfitters Local 638, 501 F.2d 622 (2d Cir. 1974); United States v. IBEW Local No. 38, 428 F.2d 144, 148-50 (6th Cir. 1970).

73. 729 F.2d 1554, 1557-58 (5th Cir. 1984) (en banc).

74. Belton, supra note 24, at 951 . The reporting period for the federal courts is from July 1 through the following June 30 .

75. Administrative OfFice of THE U.S. Courts, An Analysis of the Workload of the Federal Courts for the Twelve Month Period Ending June 30, 1983, in ANNUAL RePort of THE Director of THE Administrative Office of the United States Courts, at 134 (1983) [hereinafter 1983 Annual REPORT].

76. Id. 
5,017 cases were filed. ${ }^{77}$ After 1980 , the number of cases again began to increase substantially. In $1983,9,097$ cases were filed. ${ }^{78}$

It is unknown how many of these cases may have been individual or pro se cases and how many were class actions. In 1983, however, there were 1,137 appeals filed in civil rights employment cases. ${ }^{79}$ This is a fairly good indication that a large number of valid cases are being litigated each year.

In the vast majority of the cases filed, plaintiffs have been represented by private practitioners. From 1981 through April 1, 1984, the Justice Department had filed only thirty-seven employment cases $^{80}$ and the EEOC had filed 880 cases. ${ }^{81}$ These government cases are a miniscule proportion of the 23,061 employment discrimination cases which were filed from 1981 through 1983.82 In fact, the federal government is much more frequently a defendant in employment cases than a plaintiff. For example, in 1983, there were 806 cases commenced and 230 appeals taken in cases in which the government was a defendant, whereas the government initiated 170 cases and 51 appeals were taken in cases where the government was a plaintiff. ${ }^{83}$

Two points are immediately apparent from these statistics. First, the need for lawyers to represent Title VII complainants far outstrips the number of lawyers who are willing to undertake to represent them. Second, in practical terms, the EEOC is the only governmental agency that has sought to represent significant numbers of Title VII complainants.

One factor that is reducing the number of lawyers willing to represent Title VII complainants is the runaway cost of these lawsuits. Ten years ago, a class action of average size could be prosecuted to judgment for $\$ 5,000$ $\$ 15,000$. Today, such cases cost over $\$ 50,000$. In recognition of this reality and the fact that most cases were being brought by private practitioners, the EEOC established a litigation fund to help defray costs. While that program was woefully underfunded, it was a step in the right direction. Unfortunately, the program no longer exists. ${ }^{84}$ It would be helpful if the program were revived and expanded. Even if such funding were to become available, however, the large and important cases may not get attention unless the EEOC itself undertakes to establish a larger presence in the fight against discrimination. It needs to do so if the process of dismantling the remnants of slavery is to continue.

77. Id.

78. Id. at 135 .

79. Id. at 225.

80. Telephone interview with Dave Rose, Chief of the Employment Litigation Section of the Civil Rights Division, United States Department of Justice (Apr. 18, 1984).

81. Telephone interview with Mikle Middleton, who at the time was the Associate General Counsel for Trial Services, Equal Employment Opportunity Commission (Apr. 18, 1984). This amount is the total number of EEOC filings for fiscal years 1981 through 1983.

82. 1983 ANNUAL REPORT, supra note 75, at 135.

83. Id. at $237,246$.

84. Clarence Thomas, chairman of the EEOC, has confirmed that the program is no longer in existence. 
Public-interest legal organizations and private firms must continue to represent Title VII plaintiffs, regardless of the number of cases the EEOC commences. Apart from the reality that the government is unlikely to devote enough resources to adequately wage the fight against discrimination, the Department of Justice is increasingly advocating positions which, if successful, will halt effective enforcement. Without the help of lawyers in private practice who are prepared to champion the historic remedial purposes of Title VII, the statute will become a dead letter.

\section{$\mathrm{V}$ \\ Conclusion and Evaluation}

The effort to enforce Title VII in order to end employment discrimination has been a serious one. Moreover, it has been relatively prolonged compared to prior efforts by this country to end the practices and effects of racial discrimination. Substantial barriers to equal employment opportunity have been breached; segregated job patterns have been altered. For those who have worked to integrate the American workplace, the results have been encouraging. Jobs, at least blue-collar jobs, in paper mills, steel plants, and other industries, are no longer as defined by color as they once were. Title VII and affirmative action have opened many craft training opportunities to minority workers. For example, the number of black electricians has more than doubled from $15,872(3.2 \%)$ in 1972 to $35,480(5.6 \%)$ in $1979 .{ }^{85}$ In general, between 1972 and 1979 , a period of active Title VII enforcement and affirmative action implementation, the number of blacks working in the craft and kindred census category increased by $270,000.86$

The advances made in some of the public service professions, such as law enforcement, also have been dramatic. Litigation and affirmative action efforts have perhaps placed most emphasis on police officers. In 1970,6.3\% or 23,846 of the 375,494 policemen and detectives in the country were black. ${ }^{87}$ In $1982,9.3 \%$ or approximately 47,000 of the 505,000 police officers in the country were black. ${ }^{88}$ Other statistics also indicate marked improvement. ${ }^{89}$

Racial disparities in the workplace continue, however, with underrepresentation of blacks in the traditionally "white" jobs, especially in white collar, sales, and supervisory occupations. Of course, there is the vexing problem of the continued disproportionate unemployment rate for

85. See Bureau of the Census, U.S. Dep't of Commerce, Statistical Abstract of the United States, at 419 (1980).

86. Id.

87. I Bureau of the Census, U.S. Dep't of Commerce, Census of the Population: 1970, table 223 , at $745(1973)$.

88. Bureau of the Census, U.S. Dep't of Commerce, Statistical Abstract of the United States at $420(1984)$.

89. See, e.g., Jones, The Genesis and Present Status of Affirmative Action in Employment: Economic, Legal, and Political Realities, 70 IowA L. Rev. 901, 917-18 (1985). See generally Leonard, The Impact of Affirmative Action on Employment, 2 J. LAB. ECON. 439 (1984). 
blacks. ${ }^{90}$ While an additional 2.7 million blacks entered the workforce between 1972 and 1982, there was only an increase of 1.4 million employed black workers. ${ }^{91}$ This is a particularly troubling figure, especially in light of the projection that in the next ten years blacks will enter the workforce at twice the rate of whites. ${ }^{92}$

We do not purport to make a detailed statistical analysis, but it is clear that while we have come some distance since 1965 , there is a ways to go. We have tried to indicate in each of the sections of this article the positive developments and challenges to the continued effective implementation of Title VII. It has been a fascinating two decades of implementing Title VII, but twenty years of commitment to the remedial purpose of Title VII has been insufficient. Major challenges to the underpinnings of the effective implementation of Title VII as a remedial statute threaten to undermine or halt the statute's effectiveness. It is in the interests of all Americans that the current substantial challenges to the effectiveness of Title VII in particular, and the civil rights laws in general, be met and rejected. The EEOC and the private bar generally must take a more active role in meeting this challenge.

90. Bureau of the Census, Dep't of Commerce, supra note 88, at 409.

91. Bureau of the Census, U.S. Dep't of Commerce, America's Black Population 1970 to 1982, at 9 (1983).

92. Fullerton, The 1985 Labor Force: BLS's Latest Projections, Monthly Lab. Rev., Nov. 1985, at 17. 
